\title{
Research and Resources in Political Science at the Centre of West African Studies 1964-79
}

\section{Arnold Hughes}

\section{RESEARCH}

Although political science has been a popular subject with postgraduate students at CWAS, staff resources have never exceeded one permanent member of staff abetted periodically by a temporary lecturer or research fellow. This has restricted both the number of students who can properly be supervised and the kind of work undertaken. Nevertheless, during this period over 20 doctoral and masters' theses have been commenced or completed and a further 27 masters' dissertations submitted. Several of the latter contain original material and argument.

CWAS has never been a 'policy oriented' institution; neither has its staff, with rare exceptions, engaged in collective research projects. Instead, staff and students have worked independently on academic research, both in political science and other disciplines. Funding has come mainly from University sources for staff engaged in political research and from SSRC for the majority of research students. Research into politics has not been confined to political scientists; several theses in related areas or disciplines-sociology, economics, history and local government-deal with political themes or otherwise are of interest to political scientists.

Research interest by area has been directed mainly towards Ghana and Nigeria and, to lesser extent, Sierra Leone. One staff member is engaged in a study of Gambian politics and a Liberian student is completing a thesis on the politics of his own country. With few exceptions, students have tended to avoid French-speaking West Africa; the Anglophone field experience of supervisors and a lack of fluent French (or English in the case of Francophone African students) mainly account for this. Even so, some interest has been shown in Cameroun and Niger.

Research interest by subject has mirrored fairly accurately shifts within the study of political change. There has been a concentration on two areas-regional and local level politics, and the application of concepts derived from the new 'political economy'. There is also a strong historical dimension to political research, perhaps reflecting CWAS' strength in the historical field.

Just over half the students who have been registered for the $\mathrm{PhD}$ in political science at CWAS have been internal transfers from the masters' programme but only two have taken first degrees at Birmingham. These research students are mainly British with a sprinkling of African and North American students. To date very few part-time students have enrolled; the cost and complications of fieldwork probably account for this. The Centre has been fortunate over the years in obtaining a generous allocation of SSRC research awards which, with field supplementation, has enabled a number of its students to spend lengthy periods in West Africa.

\section{Research completed or in progress}

Members of staff Arnold Hughes is working mainly on a monograph on the activities of the Garvey Movement in black Africa during the interwar years and on a general account of Gambian politics in the twentieth century. He has published on these topics, on Nigerian politics and on political modernisation. Together with colleagues in the Institute of Local Government Studies, he recently completed a study for the ILO on participation and basic needs.

David Brown remains interested in the comparative study of local politics and in particular the Ewe community in Ghana and Togo. He has published on the latter subject.

Centre students: PhD theses completed or in preparation Theses in related disciplines are also included. Some titles are provisional. Date of completion is given in parenthesis.

Brown, D. Politics in the Kpandu area of Ghana, 1925 to 1969: a study of the influence of central government and national politics upon local factional competition. (1977)

Cohen, $D$. The CPP in Ghana: a re-evaluation.

Cohen, $R$. The role of organised labour in the Nigerian political process. (1971)

Cooksey, B. Education and class formation in Cameroun. (1978) 
Craig, $J$. The co-operative movement and pohtics in Ghana.

Crisp, J. Protest and control in the Ghanaian goldmining industry, 1898-1978.

Dennis, $C$. The process of re-unification in the education structure of Cameroun. (1974)

Denzer, L. I.T.A. Wallace-Johnson and the West African Youth League: a case study in West African radicalism. (1977)

Duffill, $M$. Politics and administration in the Lafia emirate of Northern Nigeria.

Fuglestadt, $F$. An introduction to the history of Niger in the colonial period ca. 1897 to 1957 (1977)

Higgott, $R$. Colonial origins and environmental influences in the foreign policy of a West African land-locked state: the case of Niger. (1979)

Jones, $R$. Britain's post-imperial relations with Nigeria, with particular reference to the Civil War period.

Kelly, $R$. Political consciousness and party politics in an African periphery: the Northern Ghanaian example. (1974)

Lisk, $F$. The political economy of Sierra Leone 1961-1971, with particular reference to the IMF stabilisation programme of 1966 to 1969 (1974)

Minikin, $V$. Local politics in Kono District, Sierra Leone, 1945-1970. (1971)

Mukonoweshuro, E. Politics and class formation in Sierra Leone, 1967-78.

Riley, S. Political corruption in Sierra Leone: a study of public-office centred corruption 1951-68.

Vickers, $M$. The Mid West State movement in Nigeria, 1948-1965.

Williams, $\boldsymbol{H}$. The politics of national integration in Liberia, 1847-1971.

Weaver, $G$. State corporations and party factions in Ghana, 1957-66.

Centre students: Masters' theses completed or in preparation

Clevenger, $J$. The political economy of hunger: famine in Nigeria, 1969-70. (1975)

Duffill, $M$. Political conflict in the Tiv Division of Northern Nigeria, 1960-1965. (1973)

Jones, $T$. The post-colonial state in East Africa.

May, $R$. Sierra Leone as a 'Reconciliation System', (1969)

Winstanley, $M$. The National Liberation Council: a study of the distribution of power in Ghana since 24 February 1966. (1970)

Centre students: Masters' dissertations Though not requircd to be original work, the following do contain new material or interpretation.
Crisp, J. Rural protest and class consciousness in Western Nigeria, 1968-1970. (1977)

Gibrill, $H$. The analysis of economic inequality in rural African social formations. (1975)

Jibo, $M$. The Nigerian Press and political corruption, 1974/75. (1976)

Minikin, $V$. The development of political opposition in Sierra Leone, 1961-1967. (1968)

Stanley, $G$. Military involvement in black Africa, with special reference to Dahomey, 19631975: the potential for disengagement and withdrawal of military regimes. (1976)

Waterman, $P$. Neo-colonialism, communism and the Nigerian Trade Union Congress. (1972)

\section{RESOURCES}

The University Library (including the specialist holdings in CWAS, Faculty of Law, Faculty of Education and the Institute of Local Government Studies) contains a large collection of books and journals relating to Africa and, under the SCOLMA agreement, has a special responsibility for French West Africa.

\section{Newspapers}

Of considerable interest to political historians and political scientists alike is the extensive collection of West African newspapers held by the University. Microfilm copies of colonial newspapers are deposited at CWAS and current newspaper subscriptions are in the main Library. The collection is by no means definitive and gaps exist within individual runs, particularly for the terminal colonial period. Even so it provides an intermittent coverage of events in West Africa for over a century.

\section{Gold Coast/Ghana}

African Morning Post (Accra), some issues

Ashanti Pioneer (Kumasi) 1931-62

Ashanti Times (Obuasi) 1951-54

Daily Echo (Accra) 1939-53

The Echo (Accra) 1937-38

Ghanaian Times (Accra) 1966-

Gold Coast Aborigines (Cape Coast) 1898-1902

Gold Coast Assize (Cape Coast) 1883-84

Gold Coast Chronicle (Accra) 1894-1901

Gold Coast Echo (Cape Coast), some issues

Gold Coast Free Press 1899

Gold Coast Independent (Accra) 1895-1948

Gold Coast Leader (Cape Coast) 1902-1929

Gold Coast Methodist (Cape Coast) 1886

Gold Coast Methodist Times (Cape Coast) 1897

Gold Coast Nation (Cape Coast) 1912-14

Gold Coast News (Cape Coast) 1885 
Gold Coast People (Accra) 1891

Gold Coast Pioneer (Accra) 1921

Gold Coast Spectator (Accra) 1937-38

Gold Coast Times (Cape Coast) 1874-1940

Royal Gold Coast Gazette (Accra) 1822-24

Spectator, some issues

Star of West Africa (Cape Coast) 1939

Times of West Africa (Accra) 1932-35

Vox Populi (Accra) 1930-39

Weekly Spectator (Accra), some issues

West African Gazette (Accra) 1896

West African Times (Accra) 1931-32

Western Echo (Cape Coast) 1885-87

\section{Liberia}

Observer (Monrovia) 1878-83

Nigeria

Anglo-African (Lagos) 1863-65

Daily Times (Lagos) 1960-61; 1967-

Eagle and Lagos Critic (Lagos) 1883-88

Lagos Observer (Lagos) 1882-88

Lagos Standard (Lagos) 1895-1920

Lagos Times and Gold Coast Colony Advertiser (Lagos) 1880-83

Lagos Weekly Record (Lagos) 1891-1921

Mirror (Lagos) 1887-88

Morning Post (Lagos) 1967-

New Nigerian (Kaduna) 1966-

Nigerian Chronicle (Lagos) 1908-15

Nigerian Pioneer (Lagos) 1914-34

Nigerian Times (Lagos) 1910-11

Sunday Post (Lagos) 1967-

Sunday Times (Lagos) 1967-

Times of Nigeria (Lagos) 1914-20

West African Pilot (Lagos) 1960-61; 1966-

Sierra Leone

Agency (Freetown) 1884-87

Artisan (Freetown) 1884-88

Colonial and Provincial Reporter (Freetown) 1914-20

Colony and Provincial Reporter (Freetown) 1912-13

Commonwealth (Freetown) 1888

Daily Mail (Freetown) 1958-62; 1966-

Early Dawn (Bonthe, Sherbro) 1885-1892

Freetown Express and Christian Observer (Freetown) 1882-84

Independent (Freetown) 1874-78
Methodist Herald and West African Educational Times (Freetown) 1882-88

Sawyerr's Bookselling, Printing and Stationery Trade Circular and General Advertising Medium (Freetown) 1885-86

Sierra Leone Church Times (Freetown) 1884-86

Sierra Leone Farm and Trade Report (Freetown) 1886-87

Sierra Leone Gazette (Freetown) 1808-27

Sierra Leone Weekly News (Freetown) 1884-1951

Trader (Freetown) 1891

Watchman and West African Record (Freetown) 1876-86

West African Mail and Trade Gazette (Freetown) 1920-32

West African Reporter (Freetown) 1876-84

French-speaking West Africa

Afrique Nouvelle (Dakar) 1967-

L'Essor (Bamako) 1967-

Fraternité (Abidjan) 1967-

L'Unité Africaine (Dakar) 1967-

Other newspaper holdings

West Africa (London) 1917-

West Africa and Traders Review 1900-06

Negro World (New York/Kingston) 1923-33

Blackman/Black Man (Kingston/London) 193339

Official documents on microfilm

Mic 1757-65 Nederuits Gereformeered Kerk (Dutch Reformed Church of South Africa Mission). Documents on the Tiv of Nigeria (compiled by Dr. D. C. Dorward)

Mic 1430-1 US Department of State: Political Relations-Liberia and other states. 1919-29

\section{Official publications}

CWAS and the University Library possess a large number of official publications from West Africa-annual reports; reports of commissions of enquiry; sessional papers; political ephemera, etc.-but their acquisition has not been systematic and considerable difficulties have been encountered in trying to obtain more recent publications. Individual staff members may also possess such publications: e.g. Arnold Hughes has a number of political pamphlets and official documents from The Gambia. 